\title{
Microstructure and mechanical properties of amorphous/crystalline ductile liquid immiscible Fe-Si-B-In alloy produced by two-component melt-spinning
}

\author{
Mikrostruktura i właściwości mechaniczne \\ ciągliwego stopu amorficzno-krystalicznego \\ na osnowie Fe-Si-B-In \\ wytworzonego przez odlewanie na wirujący walec \\ z tygla dzielonego
}

\begin{abstract}
The two-component melt-spun (TCMS) $\mathrm{Fe}_{71.25} \mathrm{Si}_{9.5} \mathrm{~B}_{14.25} \mathrm{In}_{5}$ alloy was produced from $\mathrm{Fe}_{75} \mathrm{Si}_{10} \mathrm{~B}_{15}$ and $\mathrm{Fe}_{67.5} \mathrm{Si}_{9} \mathrm{~B}_{13.5} \mathrm{In}_{10}$ alloys. The microstructure of the TCMS alloy was investigated by means of scanning electron microscopy (SEM) and X-ray diffraction (XRD). A tensile test of the alloy resulted in a tensile strength of $R_{m}=1040 \mathrm{MPa}$, yield strength $R_{e}=919 \mathrm{MPa}$, total plastic elongation $\varepsilon_{\text {tot }}=3.29 \%$, and traces of plastic deformation on the surface of the Fe-Si-B-In TCMS sample. Microstructural analysis of the amorphous/crystalline composite and tensile sample free surface show the reason for the ductility of the sample in relation to the $\mathrm{Fe}_{75} \mathrm{Si}_{10} \mathrm{~B}_{15}$ alloy.
\end{abstract}

Keywords: metallic glasses, X-ray diffraction (XRD), scanning electron microscopy (SEM), tensile test, ductility

\section{Streszczenie}

Stop $\mathrm{Fe}_{71,25} \mathrm{Si}_{9,5} \mathrm{~B}_{14,25} \mathrm{In}_{5}$ wytworzono w wyniku odlewania $z$ tygla dzielonego na wirujący walec miedziany dwóch stopów (metoda TCMS): $\mathrm{Fe}_{75} \mathrm{Si}_{10} \mathrm{~B}_{15}$ i $\mathrm{Fe}_{67,5} \mathrm{Si}_{9} \mathrm{~B}_{13,5} \mathrm{In}_{10}$. Mikrostrukturę stopu TCMS badano za pomocą skaningowego mikroskopu elektronowego oraz dyfraktometru

Krzysztof Ziewiec Associate Prof. Ph.D. Eng., Mirosława Wojciechowska M.Sc. Eng.: Pedagogical University of Cracow, Institute of Technology, Faculty of Mathematics, Physics and Technical Science, Krakow, Poland, Dariusz Mucha Ph.D.: Polish Academy of Sciences, Institute of Catalysis and Surface Chemistry, Krakow, Poland, Aneta Ziewiec Ph.D. Eng.: AGH University of Science and Technology, Faculty of Metals Engineering and Industrial Computer Science, Department of Physical and Powder Metallurgy, Krakow, Poland; kziewiec@up.krakow.pl 
rentgenowskiego. Z przeprowadzonej statycznej próby rozciągania uzyskano wytrzymałość na rozciąganie stopu $R_{m}=1040 \mathrm{MPa}$, granicę plastyczności $R_{e}=919 \mathrm{MPa}$, wydłużenie całkowite $\varepsilon_{\text {tot }}=3,29 \%$. Na powierzchni próbki stopu Fe-Si-B-In TCMS po zerwaniu zaobserwowano także ślady odkształcenia plastycznego. Analiza mikrostruktury otrzymanego amorficzno-krystalicznego kompozytu oraz powierzchni swobodnej próbki wyjaśniają przyczynę ciągliwości próbki w stosunku do stopu $\mathrm{Fe}_{75} \mathrm{Si}_{10} \mathrm{~B}_{15}$.

Słowa kluczowe: szkła metaliczne, dyfrakcja rentgenowska, skaningowa mikroskopia elektronowa, statyczna próba rozciągania, ciągliwość

\section{Introduction}

The ductility of amorphous matrix alloys is one of the issues that provides better applicability for various grades of metallic glass, showing excellent magnetic, electric, and mechanical properties. There are attempts to enhance the plastic deformation in these materials by forming heterogeneous microstructures of amorphous-amorphous [1-8] and amorphous-crystalline [9-15] composites. The majority of amorphous alloys are multi-component, and glass-forming generally requires high concentrations of alloying additions. On the other hand, the formation of a highly ductile phase entails the necessity for a low-alloyed solid solution in most cases. There is also the risk that any element added to the composition will ruin the special functional properties of the base alloy. Therefore, in order to produce the amorphous-crystalline composite in which the soft phase improves its ductility, one should properly choose the alloying element, and all of the above reasons should be taken into account. The ternary Fe-Si-B alloys are very-well-known for their excellent mechanical behavior and good magnetic and magnetoelastic properties as well as their prospective use in sensors and bio-sensors [16-21]. However, no reports can be found on improving the ductility of Fe-Si-B-based alloys without affecting the Fe-Si-B matrix and, thus, the deterioration of its excellent properties. On the other hand, it can be found that indium has a low affinity to iron, silicon, and boron $[22,23]$ (see Table 1). Therefore, one can anticipate that an Fe-Si-B-In system will provide good amorphization of the Fe-Si-B-rich constituents as well as liquid immiscibility of the In-rich constituent. Liquid immiscible alloys present a very strong tendency for demixing. This is the reason for using the new variation of the two-component melt spinning (TCMS) technique [5-8]. This method of production provides additional turbulent mixing of the two streams/alloys before rapid cooling on a copper roller. Therefore, the aim of this study was to prepare the liquid immiscible amorphous/crystalline Fe-Si-B-In TCMS alloy and exploring the relationship between the microstructure and its behavior during tensile testing in comparison with the traditionally melt-spun Fe-Si-B alloy. 
Table 1. Calculated enthalpies of mixing for equiatomic liquids in binary systems, $\mathrm{kJ} / \mathrm{mol}$ [23, 24]

\begin{tabular}{|c|c|c|c|c|}
\cline { 2 - 5 } \multicolumn{1}{c|}{} & Fe & Si & B & In \\
\hline $\mathrm{Fe}$ & - & $-18^{*}$ & $-11^{*}$ & $+11^{*}$ \\
\hline $\mathrm{Si}$ & - & - & $+3^{* *}$ & $+7^{* *}$ \\
\hline $\mathrm{B}$ & - & - & - & $+2^{* *}$ \\
\hline
\end{tabular}

* reference [23], ${ }^{* *}$ reference [24]

\section{Experimental}

The $\mathrm{Fe}_{75} \mathrm{Si}_{10} \mathrm{~B}_{15}, \mathrm{Fe}_{67.5} \mathrm{Si}_{9} \mathrm{~B}_{13.5} \mathrm{In}_{10}$, and $\mathrm{Fe}_{71.25} \mathrm{Si}_{9.5} \mathrm{~B}_{14.25} \mathrm{In}_{5}$ alloys were produced using 99.95 wt $\% \mathrm{Fe}, 99.95 \mathrm{wt} \% \mathrm{Si}, 99.95 \mathrm{wt} \% \mathrm{In}$, and an Fe-B ferroalloy. The precursors were arc melted under argon. The alloys were then melt spun in helium using a velocity of the copper roller of $33 \mathrm{~m} / \mathrm{s}$ and ejection pressure of $150 \mathrm{kPa}$. The $\mathrm{Fe}_{75} \mathrm{Si}_{10} \mathrm{~B}_{15}$ and $\mathrm{Fe}_{67.5} \mathrm{Si}_{9} \mathrm{~B}_{13.5} \mathrm{In}_{10}$ alloys were melt spun from a single-chamber crucible. The $\mathrm{Fe}_{71.25} \mathrm{Si}_{9.5} \mathrm{~B}_{14.25} \mathrm{In}_{5}$ two-component melt-spun (TCMS) alloy was produced by ejecting the $\mathrm{Fe}_{75} \mathrm{Si}_{10} \mathrm{~B}_{15}$ and $\mathrm{Fe}_{67.5} \mathrm{Si}_{9} \mathrm{~B}_{13.5} \mathrm{In}_{10}$ alloys [5-8]. The free surface and cross-section of the $\mathrm{Fe}_{71.25} \mathrm{Si}_{9.5} \mathrm{~B}_{14.25} \mathrm{In}_{5}$ TCMS ribbon was observed by means of an SEM. The XRD measurements of the $\mathrm{Fe}_{75} \mathrm{Si}_{10} \mathrm{~B}_{15}, \mathrm{Fe}_{67.5} \mathrm{Si}_{9} \mathrm{~B}_{13.5} \mathrm{In}_{10}$, and $\mathrm{Fe}_{71.25} \mathrm{Si}_{9.5} \mathrm{~B}_{14.25} \mathrm{In}_{5}$ TCMS were performed using a Panalytical $X$ 'pert powder diffractometer equipped with an automatic diaphragm of the primary beam, graphite monochromator of the secondary beam, and X'celerator strip detector. The measurements were performed within a range of $30-95^{\circ}$ using CuKa radiation and a constant $10 \mathrm{~mm}$ exposure length. The analysis of the obtained diffraction patterns were performed by using of Panalytical HighScore software and PDF-4 database. The tensile tests of the $\mathrm{Fe}_{75} \mathrm{Si}_{10} \mathrm{~B}_{15}$ and $\mathrm{Fe}_{71.25} \mathrm{Si}_{9.5} \mathrm{~B}_{14.25} \mathrm{In}_{5}$ TCMS ribbons were carried out. The specimens with a gauge length of $20 \mathrm{~mm}$ and width of $2.4 \mathrm{~mm}$ were prepared and tested at room temperature at a crosshead speed of $1 \mathrm{~mm} / \mathrm{min}$. Following the tensile tests, a $\mathrm{Fe}_{71.25} \mathrm{Si}_{9.5} \mathrm{~B}_{14.25} \mathrm{In}_{5}$ TCMS sample surface from near the fracture was observed.

\section{Results and discussion}

These observations are consistent with the data of mixing enthalpies of the binary systems $[22,23]$ (see Table 1). On this basis, it can be expected that $\mathrm{Fe}$, $\mathrm{Si}$, and $\mathrm{B}$ have ratherstrong affinity and they will be attracted by each other in the liquid state. On the other hand, In shows strongly positive enthalpy to $\mathrm{Fe}$ and $\mathrm{Si}$. The enthalpy of mixing between $B$ and $\mathrm{In}$ is only $+2 \mathrm{~kJ} /$ mole, but it is more probable that $\mathrm{B}$ will be attracted by Fe due to 
the high negative enthalpy of mixing between Fe and $\mathrm{B}$. Therefore, from the evidence of these observations, it can be expected that an Fe-Si-B-In system will promote the formation of amorphous/crystalline microstructures during cooling. However, it is also anticipated that a strong tendency to liquid phase partitioning will promote separation and may even lead to the formation of two different products during melt spinning (similar to what was observed in the Fe-Ni-Cu-P system [24]).

The resulting SEM microstructure of the ribbon after melt spinning from the two-chamber crucible (TCMS) is presented in Figure 1 (observed both on the free surface and cross-section). The appearance of the free-surface resembles the morphology of two immiscible fluxes that are frozen just in the course of separation (Fig. 1a) in the direction of forming a simple smooth interface. However, in the present case, this process is interrupted by cooling as a result of contact with the copper roller. Cross-section (Fig. 1 b) reveal regions of the differentiated chemical composition similar to the water-oil microstructure obtained by Kovaleva et al. [25] According to the expectation, EDS mapping shows darker regions enriched in Fe and $\mathrm{Si}$ as well as brighter ones enriched in In. The TCMS ribbon reported in the present work presents the partially separated microstructure, but the interface between Fe-Si-B-rich and Inrich constituents is fairly well-developed, which is achieved due to the strong mixing and turbulent flow of the two ejected streams while passing through the crucible orifice [5-8].

Figure 2 presents $X$-ray diffractions of the $\mathrm{Fe}_{67.5} \mathrm{Si}_{9} \mathrm{~B}_{13.5} \mathrm{In}_{10}$ and $\mathrm{Fe}_{75} \mathrm{Si}_{10} \mathrm{~B}_{15}$ ribbons obtained from the single-chamber crucible as well as the TCMS Fe ${ }_{71.25} \mathrm{Si}_{9.5} \mathrm{~B}_{14.25} \mathrm{In}_{5}$ alloy meltspun from the two-chamber crucible, where all of the diffraction patterns present the two broad diffraction maxima located for $2 \theta$ at between $40^{\circ}$ and $50^{\circ} \mathrm{C}$ and $70^{\circ}$ and $90^{\circ} \mathrm{C}$, respectively. This is due to the presence of the amorphous phase in the alloys. The XRD for $\mathrm{Fe}_{75} \mathrm{Si}_{10} \mathrm{~B}_{15}$ sample confirms that the alloy is entirely amorphous and the remaining alloys are amorphous/crystalline. However in the alloys containing indium, reflections corresponding to the series of interplanar spaces from the tetragonal $\alpha$-In phase (PDF no: 04-004-7740, space group: $14 / \mathrm{mmm}$, system 139 ) can be identified. The intensity of the peaks is higher in the $\mathrm{Fe}_{67.5} \mathrm{Si}_{9} \mathrm{~B}_{13.5} \mathrm{In}_{10}$ alloy than in the TCMS Fe $\mathrm{F}_{71.25} \mathrm{Si}_{9.5} \mathrm{~B}_{14.25} \mathrm{In}_{5}$ alloy. However, the positions of the peaks of the In solid solution present in both samples are practically identical, and the lattice parameters of the In-rich phase calculated on the base of XRD shown in Figure 2 are $a=3.244 \AA$ and $c=4.933 \AA$, which corresponds to pure indium.

The stress-strain curves obtained from the tensile tests are shown in Figure 3. During the tests, the $\mathrm{Fe}_{75} \mathrm{Si}_{10} \mathrm{~B}_{15}$ alloy reached a tensile strength of $R_{m}=1285 \mathrm{MPa}$, and for the $\mathrm{Fe}_{67.5} \mathrm{Si}_{9} \mathrm{~B}_{13.5} \mathrm{In}_{10} \mathrm{TCMS}$ alloy, this was $R_{m}=1040 \mathrm{MPa}$. However, the stress-strain curve for the $\mathrm{Fe}_{67.5} \mathrm{Si}_{9} \mathrm{~B}_{13.5} \mathrm{In}_{10} \mathrm{TCMS}$ alloy shows a yield strength at a level of $R_{e}=919 \mathrm{MPa}$ and a total plastic elongation of $3.29 \%$. 
a)

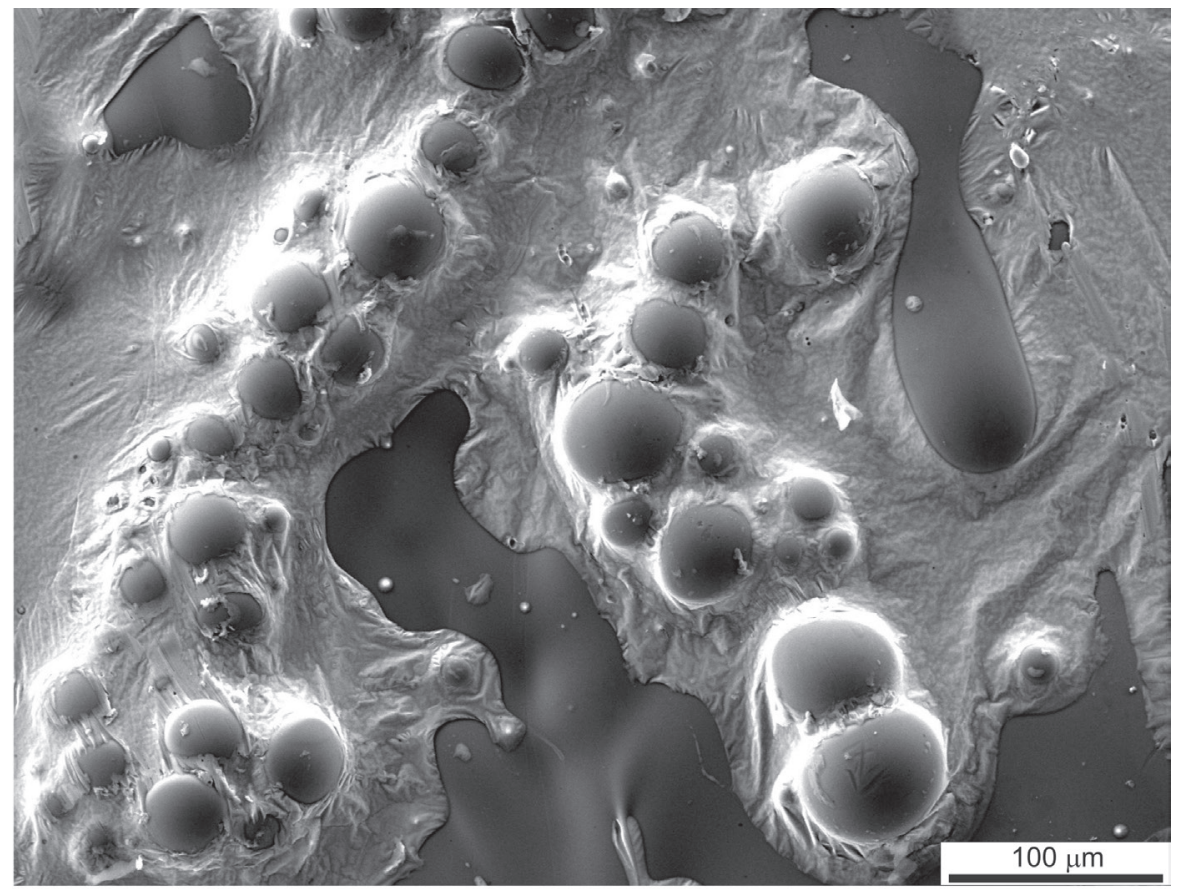

b)
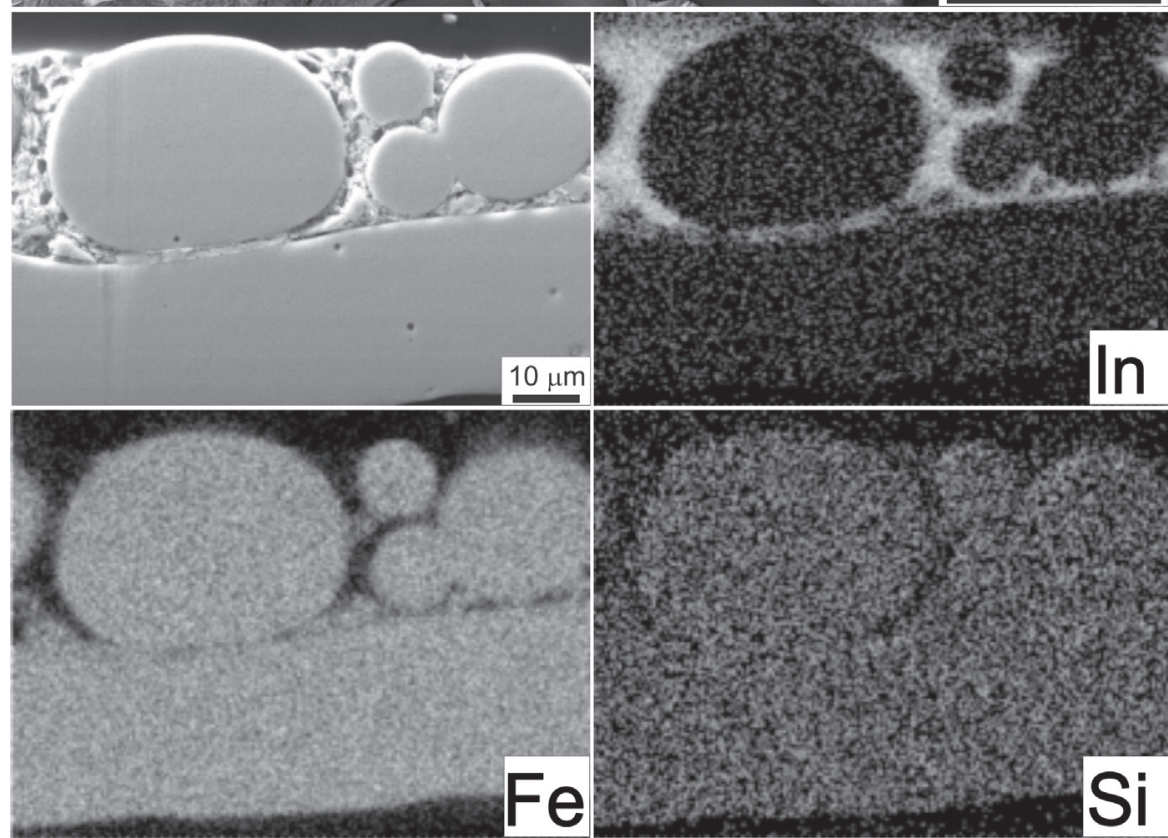

Fig. 1. Microstructure of $\mathrm{Fe}_{71.25} \mathrm{Si}_{9.5} B_{14.25} \mathrm{In}_{5}$ TCMS ribbon: a) appearance of free surface; $b$ ) longitudinal cross-section with EDS mapping of In, Fe, and $\mathrm{Si}$ 


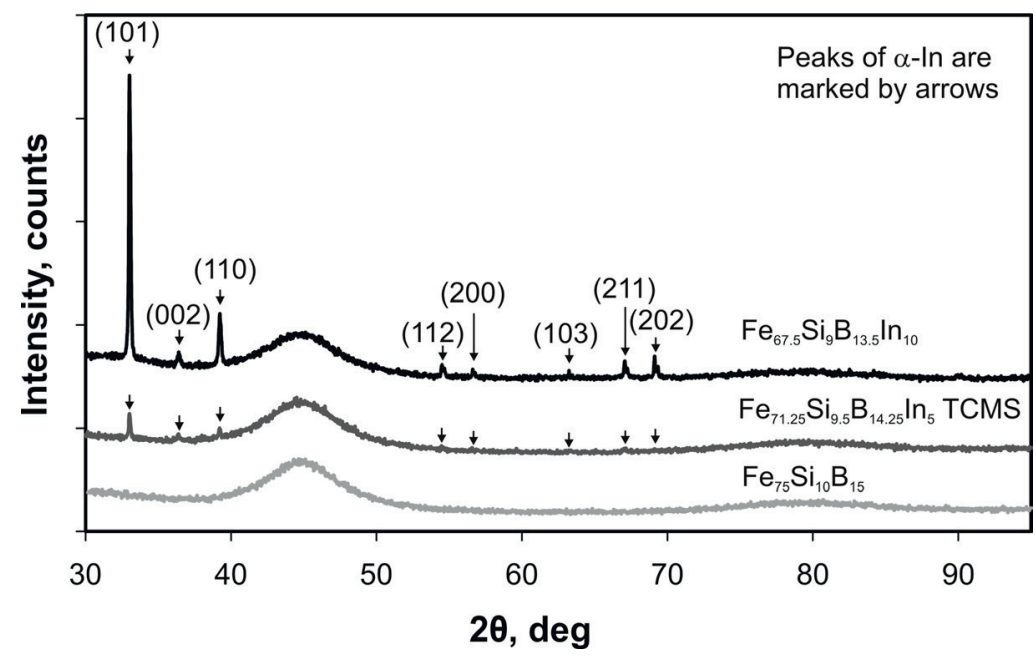

Fig. 2 XRD of $\mathrm{Fe}_{67.5} \mathrm{Si}_{9} \mathrm{~B}_{13.5} \mathrm{In}_{10}$ and $\mathrm{Fe}_{75} \mathrm{Si}_{10} \mathrm{~B}_{15}$ ribbons melt-spun from single-chamber crucible as well as TCMS Fe ${ }_{71.25} \mathrm{Si}_{9.5} B_{14.25} I_{5}$ alloy obtained from two-chamber crucible; arrows show positions of peaks from tetragonal $\alpha-\ln$

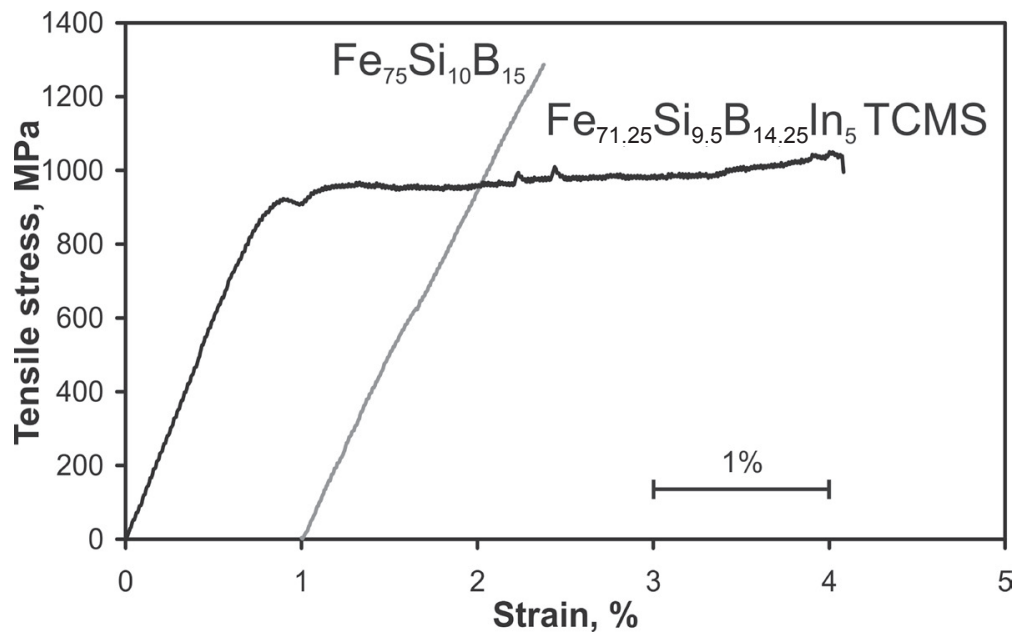

Fig. 3. Strain-stress curve from tensile test of $\mathrm{Fe}_{75} \mathrm{Si}_{10} B_{15}$ and $\mathrm{Fe}_{71.25} \mathrm{Si}_{9.5} B_{14.25} I \mathrm{n}_{5} \mathrm{TCMS}$ alloys

Figure 4 shows SEM images from the fracture of the tensile-tested $\mathrm{Fe}_{67.5} \mathrm{Si}_{9} \mathrm{~B}_{13.5} \mathrm{In}_{5}$ TCMS sample. The sample surface bears traces of plastic deformation. There are two sets of deformation markings that are arranged parallel to one of the two directions shown by the dashed line in Figure 4a. These markings were formed due to shear band propagation in the In-rich phase above the yield strength, probably during the stage of easy 
deformation. Additionally, there are places on the free surface of the sample where, during plastic deformation, the In-rich matrix flowed around the globular Fe-Si-B precipitates (Fig. 4b), while those were joined to the continuous much-more-solid part of the Fe-Si-B structure. There is a build-up of the In-rich phase above the precipitate (shown by the white arrow) and voids forming below it (indicated by the black arrow). This could be due to the fact that the precipitate is joined under the layer of the In-rich phase with the amorphous Fe-Si-B base. This means that the two phases present in the strip are coupled together and anchored to one another.

a)

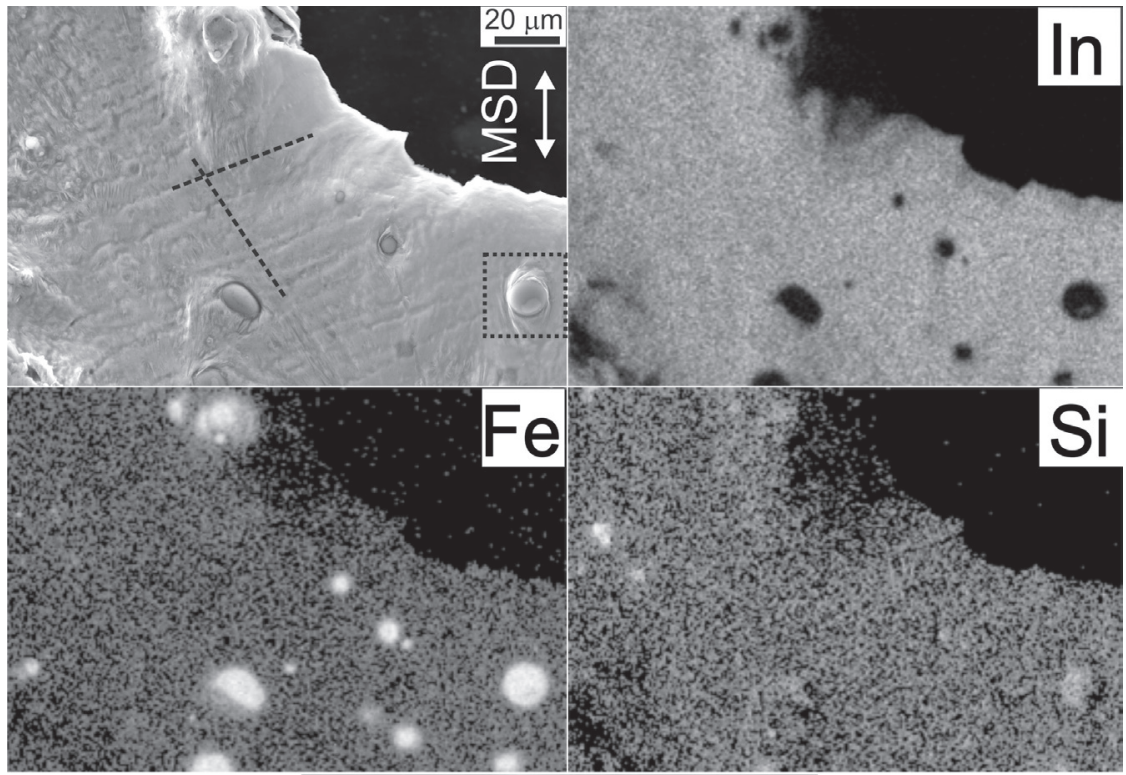

b)

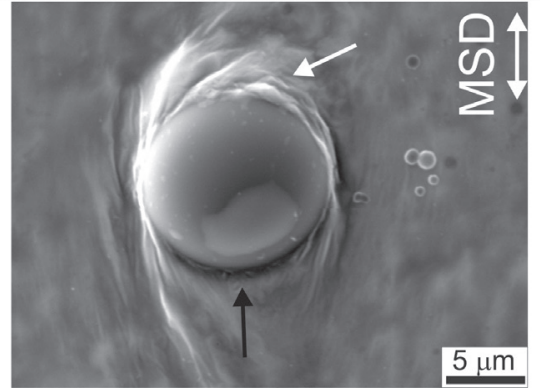

Fig. 4. SEM images of $\mathrm{Fe}_{67.5} \mathrm{Si}_{9} B_{13.5} \mathrm{In}_{5}$ TCMS alloy free surface after tensile test: a) surface area near fracture (dashed lines indicate direction of deformation markings) with mapping for In, $\mathrm{Fe}$, Si; dotted-line rectangle shows area where build-up in front of precipitate is formed); b) magnified image of build-up of In-rich phase above precipitate (white arrow) and voids below precipitate (black arrow); MSD stands for melt spinning direction 
In the case of the glass-forming alloy made from commercial purity precursors, the cooling rate from the liquid state should be rather high in order to obtain amorphization. On the other hand, crystallization of the solid solution reduces the effective cooling rate. However, in the case of the indium solid solution, crystallization occurs far below the glass-forming range of the Fe-Si-B matrix. Therefore, the formation of the solid solution probably has no detrimental influence on glass formation in this case.

\section{Conclusions}

1. The microstructure of the $\mathrm{Fe}_{71.25} \mathrm{Si}_{9.5} \mathrm{~B}_{14.25} \mathrm{In}_{5}$ TCMS ribbon consists of the amorphous Fe-Si-B phase and practically-pure-crystalline In. A morphology similar to the "water-oil" microstructure of both phases form as a result of the tendency for liquid phase partitioning in the Fe-Si-B-In system. However complete separation of the two liquids does not occur due to the use of the partition between the two liquid alloys in the crucible, very intense mixing while the two streams pass though the orifice of the crucible and rapid cooling of the stream on the copper roller.

2. The tensile strength of the $\mathrm{Fe}_{67.5} \mathrm{Si}_{9} \mathrm{~B}_{13.5} \mathrm{In}_{10} \mathrm{TCMS}$ alloy is at a slightly lower level $\left(R_{m}=1040 \mathrm{MPa}\right)$ as compared to the base alloy; i.e., $\mathrm{Fe}_{75} \mathrm{Si}_{10} \mathrm{~B}_{15}\left(R_{m}=1285 \mathrm{MPa}\right)$. However, the TCMS composite alloy shows a yield strength at a level of $R_{e}=919 \mathrm{MPa}$ and a total plastic elongation of $3.29 \%$ due to the specific amorphous/crystalline microstructure.

3. Observation of the surface near the fracture of the $\mathrm{Fe}_{67.5} \mathrm{Si}_{9} \mathrm{~B}_{13.5} \mathrm{In}_{5}$ TCMS alloy shows that the plastic deformation occurring before the fracture is localized in the deformation markings. Plastic deformation was also found around the globular Fe-Si-B precipitates that are coupled with the continuous solid part of the Fe-Si-B structure. This can be associated with the fact that the two phases are coupled together and anchored to one another.

\section{Acknowledgement}

The study was financially supported by National Science Center (Project No. 2012/05/B/ ST8/ 02644).

\section{Reference}

[1] Chang H.J., Yook W., Park E.S., Kyeong J.S., Kim D.H.: Synthesis of metallic glass composites using phase separation phenomena. Acta Materialia, 58 (2010), 2483-2491

[2] Kuan S.Y., Chou H.S., Liu M.C., Du X.H., Huang J.C.: Micromechanical response for the amorphous/amorphous nanolaminates. Intermetallics, 18 (2010), 2453-2457 
[3] Mattern N., Gemming T., Thomas J., Goerigk G., Franz H., Eckert J.: Phase separation in Ni-Nb-Y metallic glasses. Journal of Alloys and Compounds, 495 (2010), 299-304

[4] Kim D.H., Kim W.T., Park E.S., Mattern N., Ecker J.: Phase separation in metallic glasses. Progress in Materials Science 58 (2013), 1103-1172

[5] Ziewiec K., Prusik K., Bryła K., Ziewiec A.: Microstructure of the Fe-Ni-P melt-spun ribbons produced from the single-chamber and from the double-chamber crucibles. Solid State Phenomena, 203-204 (2013), 361-367

[6] Ziewiec K., Błachowski A., Ruebenbauer K., Ziewiec A., Prusik K., Latuch J., Zięba M., Bryła K.: Microstructure of the Ni-Fe-Cu-P melt-spun ribbons produced from the single-chamber and from the double-chamber crucibles. Journal of Alloys and Compounds, 615 (2014), S29-S34

[7] Różycka M., Ziewiec K., Błachowski A., Ruebenbauer K., Prusik K.: Microstructure and fracture surface of the two-component melt-spun amorphous/amorphous composite. Journal of Non-Crystalline Solids, 412 (2015), 49-52

[8] Ziewiec K., Wojciechowska M., Błachowski A., Ruebenbauer K., Jankowska-Sumara I., Prusik K., Mucha D., Latuch J.: Microstructure, fracture, and thermal stability of Ni-Fe-Cu-P-B two-phase amorphous composite produced from the double-chamber crucible. Intermetallics, 65 (2015), 15-21

[9] He J., Jiang H., Chen S., Zhao J., Zhao L.: Liquid phase separation in immiscible Ag-Ni-Nb alloy and formation of crystalline/amorphous composite. Journal of Non-Crystalline Solids, 357 (2011), 3561-3564

[10] He J., Li H., Yang B., Zhao J., Zhang H., Hu Z.: Liquid phase separation and microstructure characterization in a designed Al-based amorphous matrix composite with spherical crystalline particle. Journal of Alloys and Compounds, 489 (2010), 535-540

[11] Nagase T., Suzuki M., Tanaka T.: Amorphous phase formation in Fe-Ag-based immiscible alloys. Journal of Alloys and Compounds, 619 (2015), 311-318

[12] Ziewiec K., Kędzierski Z.: The microstructure development in Fe32Cu20Ni28P10Si5B5 immiscible alloy and possibilities of formation of amorphous/crystalline composite. Journal of Alloys and Compounds, 480 (2009), 306-310

[13] Ziewiec K.: Characterization of immiscible Ni78Ag2P20 alloy and formation of amorphous/crystalline composite. Journal of Non-Crystalline Solids, 355 (2009), 2540-2543

[14] Ziewiec K., Kędzierski Z., Zielińska-Lipiec A., Stępiński J., Kąc S.: Formation properties and microstructure of amorphous/crystalline composite Ag20Cu30Ti50 alloy using miscibility gap. Journal of Alloys and Compounds, 482 (2009), 114-117

[15] Ziewiec K., Malczewski P., Boczkal G., Prusik K.: Formation and properties of amorphous/crystalline ductile composites in Ni-Ag-P immiscible alloys. Solid State Phenomena, 186 (2012), 216-221

[16] Luborsky F.E., Becker J.J., Walter J.L., Liebermann H.H.: Formation and magnetic properties of Fe-B-Si amorphous alloys. IEEE Transactions on Magnetics, 3 (1979), 1146-1149

[17] ${ }^{\oplus}$ Metglas 2605 SA1 Iron Based Alloy, Metglass ${ }^{\circledR}$ Inc., 440 Allied Dr. Conway, SC - 29526

[18] Suwa Y., Agatsuma S., Hashi S., Ishiyama K.: Study of strain sensor using FeSiB Magnetostrictive thin film. IEEE Transactions on Magnetics, 46, 2 (2010), 666-669

[19] Chiriac H., Marinescu C.S.: New position sensor based on ultra-acoustic standing waves in FeSiB amorphous wires. Sensors and Actuators A, 81 (2000) 174-175

[20] Li S., Horikawa S., Park M., Chai Y., Vodyanoy V.J., Chin B.A.: Amorphous metallic glass biosensors. Intermetallics, 30 (2012), 80-85

[21] Poletti M.G., Battezzati L.: Assessment of the ternary Fe-Si-B phase diagram. CALPHAD: Computer Coupling of Phase Diagrams and Thermochemistry, 43 (2013), 40-47 
[22] Boer F.R., Boom R., Mattens W.C.M., Miedema A.R., Niessen A.K.: Cohesion in metals: transition metal alloys. Cohesion and structure, vol. 1. Elsevier Science, Amsterdam 1988

[23] Takeuchi A., Inoue A.: Mixing enthalpy of liquid phase calculated by Miedema's scheme and approximated with sub-regular solution model for assessing forming ability of amorphous and glassy alloys, Intermetallics, 18, 9 (2010), 1779-1789

[24] Ziewiec K., Bryła K., Błachowski A., Ruebenbauer K., Mucha D.: Characterization of microstructures and amorphization in Ni-Cu-Fe-P system. Journal of Alloys and Compounds, 483 (2009), 585-588

[25] Kovaleva L.A., Zinnatullin R.R., Mullayanov A.I., Mavletov M.V., Blagochinnov V.N.: Microstructure evolution of water-oil emulsions in high-frequency and microwave electromagnetic fields. High Temperature, 51, 6 (2013), 870-872 